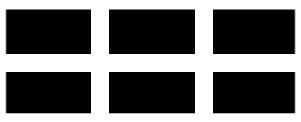

THE WILLIAM DAVIDSON INSTITUTE AT THE UNIVERSITY OF MICHIGAN BUSINESS SCHOOL

\title{
Understanding Czech Long-Term Unemployment
}

By: Štěpán Jurajda and Daniel Münich

William Davidson Working Paper Number 498

August 2002 


\title{
Understanding Czech Long-Term Unemployment
}

\author{
Štěpán Jurajda and Daniel Münich \\ CERGE-EI \\ CEPR \\ WDI
}

August 7, 2002

\begin{abstract}
A bstract
One potential impact of the looming EU accession of Central European economies is unemployment hysteresis working through long-term unemployment (LTU). In this paper, we explore the mechanisms of LTU by providing a detailed description of the recent rise in Czech LTU following the recession of 1997 . We place the Czech evidence in international perspective using, e.g., VAR-based simulations, and focus on the role of welfare benefits in driving LTU.
\end{abstract}

Keywords: Unemployment, Transition, Flexibility, Czech Republic

A cknowledgements Jurajda is also affiliated with IZA, Bonn. This research was supported by a grant No. P981129-R from the Phare ACE Program.

A ddress CERGE-EI, POB 882, Politických vězñu 7, Prague, Czech Republic. E-mail: s t epa n. j ur aj da @c er ge - ei . cz, daniel.muni ch@cerge-ei . c z CERGE-EI is a joint workplace of the Center for Economic Research and Graduate Education, Charles University, and the Economics Institute of the Academy of Sciences of the Czech Republic. 


\section{William Davidson Institute Working Paper 498}

\section{Introduction}

Long-term unemployment (LTU) severely affects both individuals and public budgets. For unemployed workers, extended periods of joblessness result in loss of attachment to labor force, degrading human capital as well as health, and increasing chances of poverty. Public budgets suffer because of loss of tax revenue and increasing expenditures on unemployment insurance, welfare and health care.

LTU is also potentially important (as opposed to short-term unemployment) because it features as the culprit in the "unemployment hysteresis" hypotheses. According to one such theory, described in, e.g., Layard et al. (1991), short-lived decreases in aggregate demand may persistently raise unemployment because long-term unemployed do not search very hard for jobs and therefore do not exert sufficient downward pressure on wages. In absence of a wage reduction, firms are not induced to hire more labor and LTU supports higher unemployment. ${ }^{1}$ Alternatively, the mechanism of a permanent effect of LTU on unemployment level may work through loss of skills of unemployed workers as in Pissarides (1992).

Understanding the strength of such mechanisms is an important task for the countries hoping to join the European Union (EU). First, high LTU is among the distinctive features of many EU labour markets. ${ }^{2}$ Second, the reallocation induced by EU accession may lead to a rise in LTU and, hence, to a persistent increase in unemployment levels. Third, LTU incidence rose rapidly in many transition economies at the end of the first transition decade (OECD, 1999). Yet, to-date, little information is available on the nature of LTU in pre-accession countries. ${ }^{3}$

\footnotetext{
${ }^{1}$ The evidence on this issue is weak, which Machin and Manning (1999) explain by lack identification: The data do not allow separate estimation of the effects of unemployment duration structure and unemployment dynamics.

${ }^{2}$ This is often blamed on employment protection policies; see, e.g., Blanchard and Portugal (2001).

${ }^{3}$ One exception is Gora and Schmidt (1997) who provide a detailed breakdown of Polish unemployment in the mid 1990s. See also Klugman et al. (2002) for recent work on poverty in transition.
} 


\section{William Davidson Institute Working Paper 498}

In this paper, we explore the mechanism of LTU rise in pre-accession economies using the case of the Czech Republic. In particular, we provide descriptive evidence on the nature of the recent increase in LTU experienced in the Czech Republic in the aftermath of its 1997 recession. First, we look at the aggregate evolution of Czech long-term unemployment from 1994 to 2001, place the findings in international perspective, and contrast the evolution of the usual LTU definition with broader concepts. Second, we inquire about the accounting sources of LTU in terms of inflows, outflows, and duration structure, and ask about the persistence of the LTU rise. We also study the demographic, industrial, and regional composition of LTU. Finally, we focus on the role of welfare benefits as one of the potentially important policy variables related to LTU.

\section{Data}

The Czech Republic is no exception in offering two sources of information on unemployment and its duration structure: the Labor Force Survey and the administrative Unemployment Registry (UR).

The UR is a collection of data reports from the District Labor Offices (DLOs), which contain both the district labor force and the quarterly number of registered unemployed. Here, it is important to note that unemployment registration is a necessary condition not only for receiving unemployment benefits, but also for collecting social benefits. The UR data also provide information on LTU incidence, unemployment inflows and outflows (the number of unemployed in each of duration groups), and reported vacancies. This data is collected by the labor market administration, which also uses the UR data to learn about unemployment. However, the DLOs report LTU figures broken down only by gender, which ignores other important characteristics of longterm unemployed. Hence, we also use the individual-level information from the Labor Force Survey (LFS).

The Czech LFS (Výběrové šetření pracovních sil) is a large rotating household sample providing the internationally comparable ILO (International Labour Organization) definition of unemploy- 


\section{William Davidson Institute Working Paper 498}

ment. While it is not representative at the level of 77 districts, it allows one to study LTU at the level of an individual. There are about 26,5 thousands households with over 70 thousand individuals surveyed every quarter, representing about $0,8 \%$ of all permanently occupied dwellings. The ILO unemployment status (not working, not self-employed, searching for a job, and ready to start working) is identified using answers to questions about individual work and job search activities performed in the reference week.

Most importantly for our analysis, the duration of unemployment in the UR data is measured since the time of registration (which may be later than the time of job loss). In LFS, unemployment duration is identified using the question "For how long are you seeking a job?". 4

The two data sources are complementary in many respects and we will rely on both of them. The only problem would be if measured unemployment would be much different in the two data sets. Fortunately, this is not the case: In the period we study, the two definitions of unemployment have evolved in close tandem in the Czech Republic. ${ }^{5}$

\section{M acroeconomic B ackground}

The Czech Republic has gained respect of observers of transition economies since within three years of the "velvet revolution," the government liberalized nearly all prices, privatized much of the economy, decentralized wage setting, and opened the country to world trade while maintaining a relatively balanced budget, low inflation, and low unemployment (below 4 percent until 1995). In sharp contrast, citizens of other new post-soviet democracies, have been severely traumatized by the rapidly emerging double-digit unemployment rates in the early stages of transition. However,

\footnotetext{
${ }^{4}$ In following the ILO definition, we do not use the alternative question of "When did you finish your last employment?". Alternatively, one could determine duration by tracking unemployed individuals over time (quarters). However, each individuals is surveyed for only 5 consecutive quarters. As a result, there would be many left and right censored spells of unemployment.

${ }^{5}$ There is, however, a large discrepancy in LTU incidence, which we discuss in Section 4.3.
} 
while the level of unemployment in many other EU-candidate countries exhibited a declining trend in the late 1990's, the Czech Republic unemployment rose rapidly during the recession of 1997.

Table 3.1: Real GDP Growth and ILO Unemployment Rate in the Czech Republic

\begin{tabular}{ccccccccc}
\hline \hline & 1994 & 1995 & 1996 & 1997 & 1998 & 1999 & 2000 & 2001 \\
\hline Unemployment rate & 4.4 & 4.1 & 3.9 & 4.8 & 6.5 & 8.8 & 8.9 & 8.2 \\
GDP growth (real) & 2.2 & 5.9 & 4.8 & -1.0 & -2.2 & -0.2 & 3.1 & 3.6 \\
\hline \hline
\end{tabular}

This evolution is shown in Table 3.1, which also displays GDP growth with its rather sharp downturn in 1997 and 1998 following rapid grow of 1995-1996. While GDP declined little over the whole year 1999, the recession was still deep at the beginning of 1999, with industrial production dropping 11.3 per cent year on year in January and with a dramatic slowdown of inflation. The most important labor-market-related cause of the recession was an unsustainable growth of wages surpassing productivity growth. Yet, the recession was largely demand driven, making it similar to cyclical recessions in developed economies (see, e.g., Jurajda et al., 1999).

\section{Results}

The two widely used measures of LTU are the LTU rate (the ratio of the number of long-term unemployed to the size of the labor force) and the LTU incidence (the ratio of the number of longterm unemployed to the number of all unemployed). We rely on these definitions below and also follow the usual practice in that we consider those workers who have spent over one year jobless and searching as long-term unemployed.

\subsection{A ggregate LTU and Broader Definitions}

Figure 4.1 plots the annual evolution of unemployment during 1994-2001 using the LFS data. The upper left graph documents the rise in ILO unemployment (U) rate during the late 1990s together 


\section{William Davidson Institute Working Paper 498}
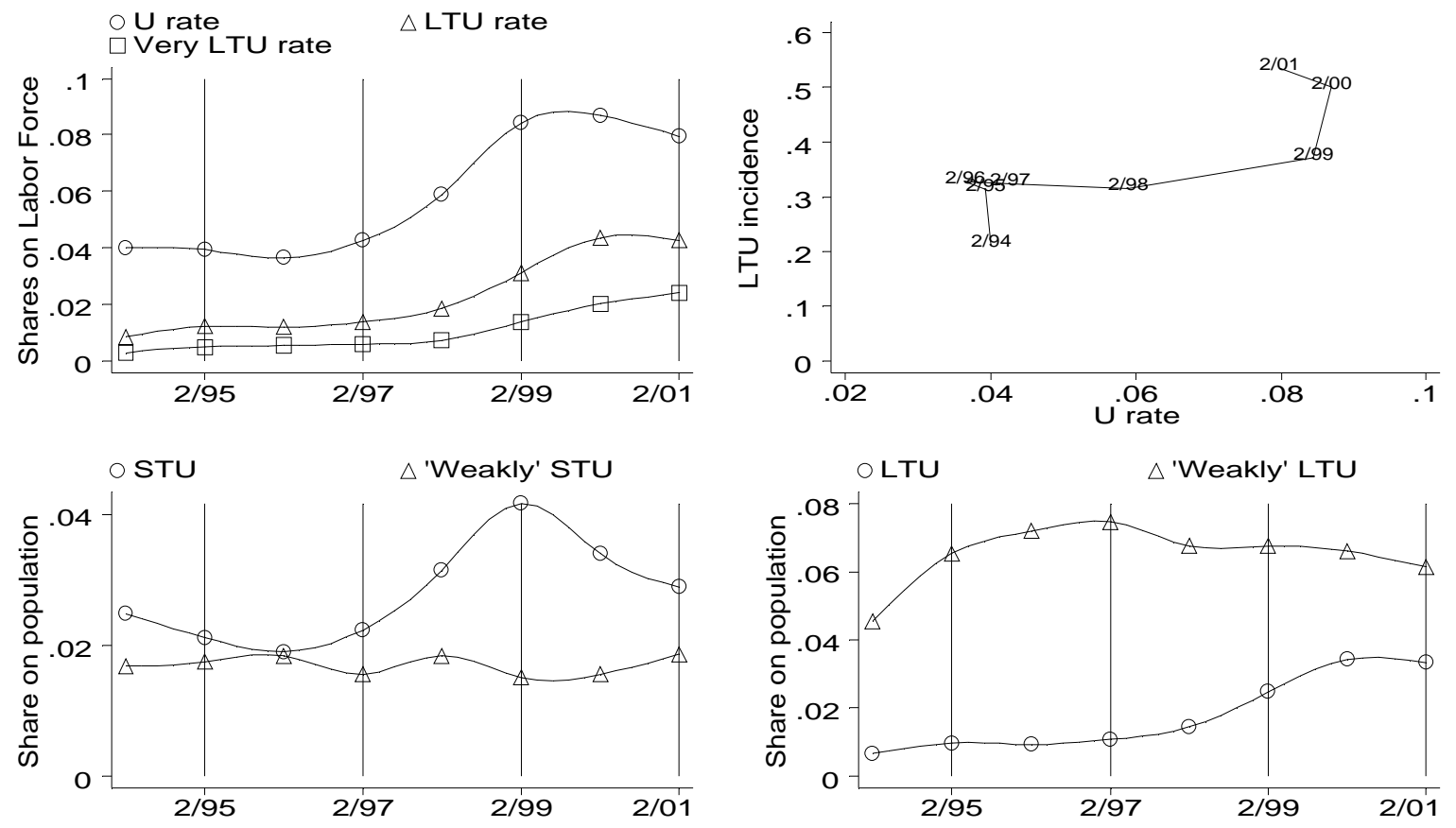

Figure 4.1: Unemployment [U] and Long-Term Unemployment [LTU]

with the somewhat delayed rise in LTU rate. The third series depicts the share on labor force of those who have been unemployed for over 2 years (very LTU). While the recession of 1997 led to a doubling of the overall unemployment rate, the LTU rate rose by a factor of four between 1996 and 2000. Moreover, at the end of our sample frame, over half of long-term unemployed have been jobless for over two years. These figures testify to the dramatically increased importance of prolonged unemployment on the Czech labor market.

The upper right graph of Figure 4.1 contrasts the evolution of the overall unemployment rate with the share of LTU on all unemployed-the measure of LTU incidence. We see that LTU incidence remained fairly stable between 1995 and 1999 and increased only between 1999 and $2001 .^{6}$ Furthermore, the share of long-term unemployed continued to rise during 2001 even as the overall

\footnotetext{
${ }^{6}$ The stability of LTU incidence during the mid 1990s is caused by the increasing inflow of (short-term) unemployed during the recession, see Section 4.3.
} 


\section{William Davidson Institute Working Paper 498}

unemployment rate somewhat declined.

During a recession, many workers become unemployed, many unemployed workers become longterm unemployed, and many of those facing LTU may become marginally attached to the labor force so that they are not coded as ILO unemployed. ${ }^{7}$ The bottom two graphs of Figure 4.1 therefore compare our typical LTU measures to an alternative broader definition of unemployment, which aims to capture workers who may have been LTU but whose job search (and, hence, laborforce attachment) could have been weakened by prolonged joblessness. We use individual-specific information contained in the LFS to categorize as "weakly" unemployed those workers in productive age who have no disabilities, are neither working nor searching for work, and do not report any explicit reason why they do not work. More specifically, we consider those individuals who are usually defined as out-of-the-labor-force but who report one of the following reasons for being jobless: maternity leave of over 3 years, short term sickness, strike, family reasons, early retirement, other reasons, waiting before job starts, do not want/need to work, discouraged from job search. For example, Czech workers are well known for their use of sickness leaves which start right before layoffs (Jurajda et al., 1999) and not counting these workers as unemployed may underestimate total effective unemployment. Note that the group of "weakly" unemployed does not contain those workers who report to be unemployed according to the ILO definition (jobless and searching).

The bottom right graph of Figure 4.1 contrast the shares on population of workers who are long-term unemployed according to the ILO definition of unemployment and those individuals who are "weakly" unemployed according to our broader unemployment concept. ${ }^{8}$ We use population ${ }^{9}$

\footnotetext{
${ }^{7}$ Furthermore, the distinction between LTU and out-of-the-labour-force may be difficult to make in transition countries, where the communist practice of full employment did away with the concept of labour-force participation and where standard labour-market institutions have developed only recently.

${ }^{8}$ We use the answer to the question "How long have you been jobless?" to measure the length of "weak" unemployment.

${ }^{9}$ We use population of 15 to 60 years of age in case of men and 15-55 years of age in case of women, reflecting
} 


\section{William Davidson Institute Working Paper 498}

as a denominator instead of the labor force (which itself depends on the definition used). We see that during the aftermath of the recession the number of "weakly" unemployed has actually somewhat decreased, which makes it unlikely that our LTU definition is substantially underestimating the increase in Czech long-term joblessness. For completeness, we also present the short-term unemployment rates according to the two definitions of unemployment in the bottom left graph. ("Short-term" here refers to less than 12 months.) Here, we see no substantial impact of the recession on the fraction of population that has been jobless only shortly and is marginally attached to the labor force.

This finding sheds light on two alternative mechanisms of labor-force participation during a recession. In theory, business cycle affects employment in two different ways: through the added worker effect and through the discouraged worker effect (see, e.g., Borjas, 1996). According to the added worker hypothesis, workers enter the labor market during recessions. This is a group of previously "weakly" unemployed individuals whose household partner becomes unemployed or faces wage cuts during a recession. As household income declines, "weakly" unemployed members find work or at least start searching to make up for household income losses. This story may correspond to mothers on extended maternity leaves, youth, etc. On the other hand, the discouraged worker effect concerns unemployed workers loosing their hopes of finding a job during a recession. Rather than incur job search, workers simply wait for economic recovery. The bottom right graph of Figure 4.1 therefore suggests the presence of a weak added worker effect on the Czech labor market.

\subsection{International Comparison}

In 2001, the number of unemployed Czech workers stood at around $8.2 \%$ of the labor force and over half of these workers have been jobless for over one year. How large are these values in terms of international comparison? The top panel of Table 4.1 displays recent values of unemployment 
Table 4.1: Unemployment and LTU rate in Selected Countries

\begin{tabular}{lcc}
\hline \hline & U rate & LTU rate \\
\hline Czech Republic & 8.2 & 4.3 \\
Hungary & 5.8 & 2.7 \\
Poland & 18.2 & 7.8 \\
Slovak Republic & 18.6 & 10.2 \\
Lithuania & 12.6 & 3.5 \\
\hline Denmark & 6.7 & 1.7 \\
Finland & 12.8 & 3.4 \\
France & 11.2 & 4.5 \\
Germany & 8.2 & 3.9 \\
Portugal & 5.6 & 2.6 \\
Spain & 19.3 & 10.1 \\
Sweden & 7.9 & 1.7 \\
United Kingdom & 7.7 & 2.9 \\
United States & 5.4 & 0.5 \\
\hline \hline Notes: Transition data from 2001, except Slovakia from 2000. \\
Western figures are averages over 1991-2001. Source: OECD in \\
Figures, OECD employment Outlook, OECD Main Indicators, \\
Lietuvos darbo rinka skaiciais 1991-2000. & \\
\hline
\end{tabular}

and LTU in a set of transition economies, while the bottom panel lists time averages of unemployment and LTU from selected western economies. As documented by the Table, Czech overall unemployment remains low compared to that of other post-communist countries in the region, with the notable exception of Hungary. The recent Czech LTU rate is similar to that of Germany or France, which ranks it high in comparison to many EU countries.

However, to say how high Czech LTU of 2001 is in comparison to other countries, one should ideally condition on the phase of the business cycle. During an economic slump, the incidence 


\section{William Davidson Institute Working Paper 498}

of LTU typically first decreases due to a strong inflow of short-term unemployed, but then rises as the large inflow cohorts find it difficult to leave unemployment. One should therefore perform comparisons of LTU level whilst matching on similar business cycle episodes or using long-term averages. Hence the use of time averages of LTU for western economies in Table 4.1. Long-term LTU averages are not useful for transition economies, where the LTU evolution during the first years of the 1990s reflects the initial transition recession and is not necessarily informative about the current working of the labor markets.

The comparison offered by Table 4.1 may therefore be quantitatively misleading in that it does not condition on the same size of the recession (GDP decline). LTU levels in other countries might have been higher if they were facing a recession as severe as the one experienced by the Czech economy in the late 1990s. To gain a more easily interpretable cross-country comparison, we simulate the behavior of western economies if they were to start with Czech initial conditions and undergo a similar decline in GDP.

This experiment is performed by estimating a VAR (vector auto-regression) system with unemployment rate, long-term unemployment rate and GDP growth for a western economy, where a sufficiently long time series of LTU is available, and then imposing the Czech values of the three variables as of 1997 as well as the Czech GDP evolution of the late 1990s on the estimated system. The predicted evolution of unemployment and LTU rates can then be compared to the actual Czech data to obtain a more meaningful quantitative comparison of the LTU increase related to a given GDP shock. ${ }^{10}$

\footnotetext{
${ }^{10}$ There are many complex channels linking output growth with unemployment indicators. The VAR method does not differentiate between these macroeconomic effects, but, rather, provides a "black box" with accurate fit of the time series data (Sims, 1980). The validity of our cross-country comparisons depends on a correct specification of the VAR system and on the assumption of similar evolution of other relevant variables, such as labor-force participation. Yet, we feel that it serves as a useful first step in developing a simple way of comparing LTU levels free of the effect of the current stage of the business cycle.
} 


\section{William Davidson Institute Working Paper 498}
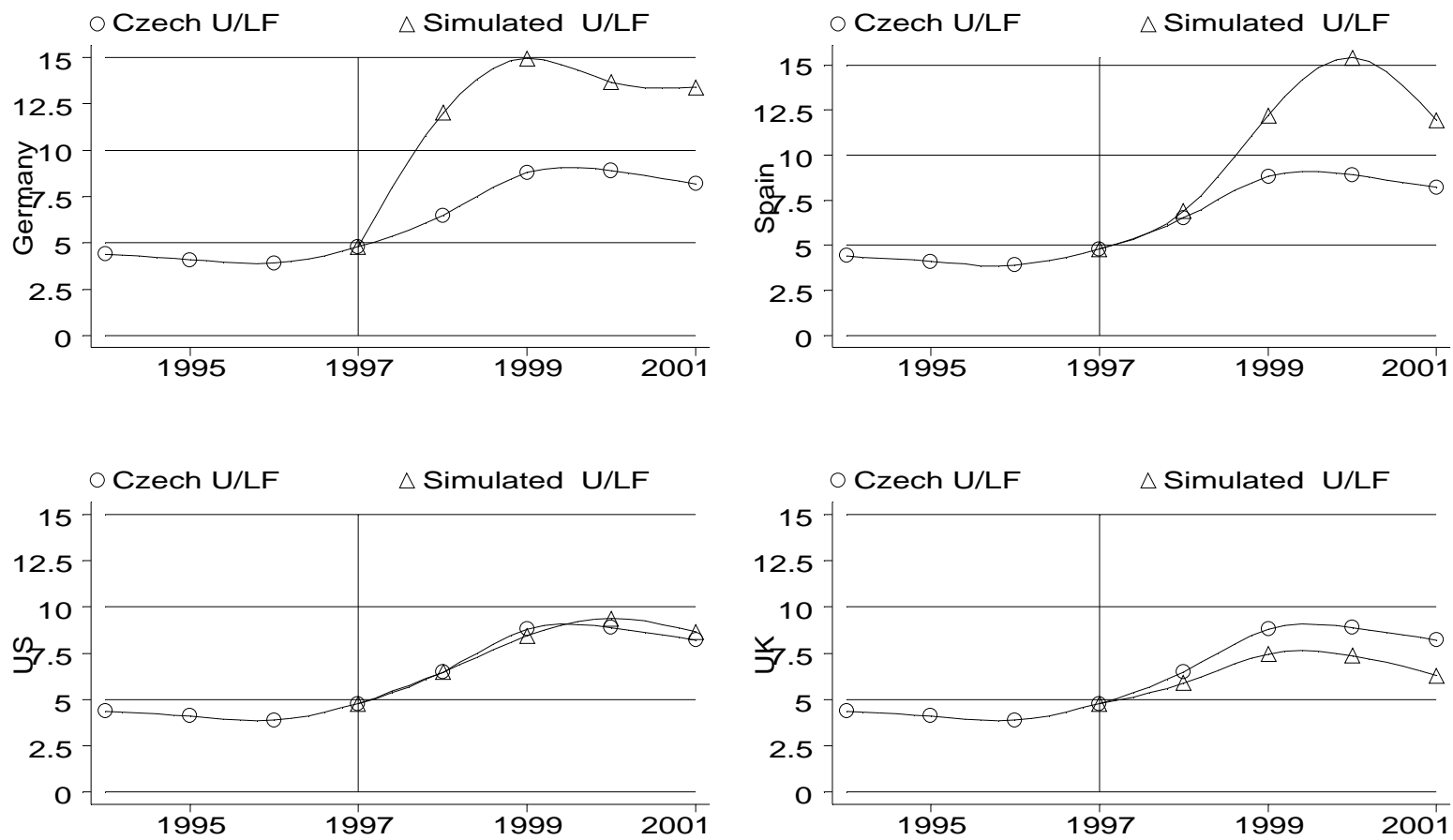

Figure 4.2: Simulated Impact of Czech Recesion on Western Unemployment

We perform the simulations four times: for Germany, UK, US, and Spain. We chose UK and Spain to contrast two European countries with high and low labor-market flexibility, respectively. We select the US as an example of a very flexible labor market and Germany because of its proximity to the Czech Republic. The data used in the estimation are annual time series from 1981 to $2001 .^{11}$ Figures 4.2 and 4.3 present the results of our simulations. The first Figure focuses on the simulated evolution of overall unemployment, while the second one displays the predicted LTU rates. Each graph of each Figure then contrasts the Czech actual evolution of unemployment during the late 1990s with the model prediction for western countries under the Czech GDP scenario. For example, focusing on the upper right graphs, the simulations suggest that were Spain to experience the Czech

\footnotetext{
${ }^{11}$ The data come from the OECD Compendium and Employment Outlooks. GDP is modeled as annual growth rate while other two labor market indicators are entered as first differences. We use the AIC criterion to identify the optimal lag structure as 3 lags. The model passes the Omnibus normality statistic test of residual autocorrelation.
} 


\section{William Davidson Institute Working Paper 498}
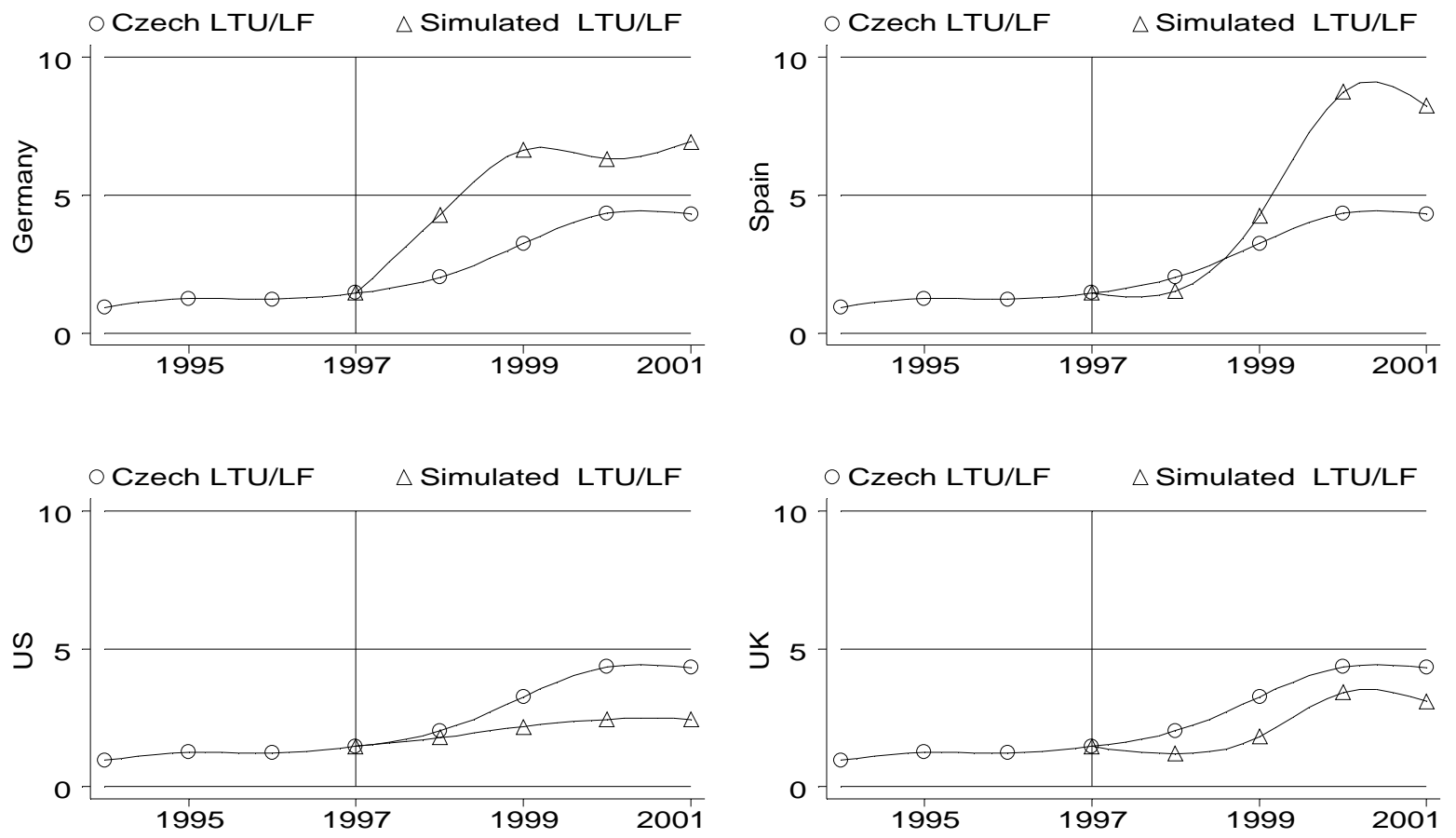

Figure 4.3: Simulated Impact of Czech Recesion on Western LTU

recession of 1997, both its unemployment and LTU rates would have increased almost twice as high compared to the Czech actual evolution. ${ }^{12}$ On the other hand, the U.S. is predicted to experience a similar rise in unemployment accompanied by a much lower increase in LTU. The Czech labor market also appears somewhat inferior to that of the UK in its ability to avoid unemployment and LTU in reaction to a severe GDP slump. ${ }^{13}$

In sum, we find that the Czech LTU level is similar to those of the EU member states, but that

\footnotetext{
${ }^{12}$ Our findings on Spain are in line with those of Castillo et al. (1998), who find long-lasting aggregate demand shocks on unemployment. The authors refer to differences in unemployment insurance system, the only notable institutional difference, to explain the differences in labor-market reaction to aggregate shocks.

${ }^{13}$ The estimated VAR models can be described using the impulse response to $1 \%$ negative exogenous drop in GDP. These are available upon request. Both the UK and US display small impacts on unemployment and especially LTU, while the responsiveness of Spanish unemployment to GDP shocks is high, and Germany ranks somewhere between the UK and Spain.
} 


\section{William Davidson Institute Working Paper 498}

the rise in Czech LTU experienced during the recent recession seems to compare favorably to what one would expect during a similar recession in, e.g., Germany.

\subsection{Duration Structure}

Now that we have marshalled evidence about the size and evolution of Czech LTU, we will analyze its structure to understand its sources. The focus of this paper is on LTU-we do not ask what drives unemployment, but ask about the determinants of the duration structure of unemployment. There are three underlying ingredients determining the duration structure of unemployment, three "accounting" sources of LTU: (i) the average outflow rate (averaged over all durations), (ii) the inflow rate, and (iii) the duration dependence (the dependence of the outflow probability on the time spent in unemployment).

To study the duration structure of unemployment we rely on the Unemployment Registry (UR) data. The UR data is well suited for the study of duration structure because it contains consistently defined time series of inflows and outflows at different durations based on the census of all registered. Also note that analyzing the evolution of long-term registered unemployment is important because only the registered unemployed are eligible for social benefits; hence, the UR LTU is the relevant variable in terms of welfare expenditures. ${ }^{14}$

The upper left quadrant of Figure 4.4 plots the overall unemployment rate, LTU rate and LTU incidence, all based on the UR data. The overall unemployment rate based on the LFS data evolved in perfect parallel with the registered unemployment rate during our sample frame. However, over time, there is a substantial difference in the incidence of LTU in the two data sources: in 2001, the

\footnotetext{
${ }^{14}$ Aggregate hazard rates could be also computed from LFS data, but their accuracy is limited by the low number of observations available. LFS is a rotating panel with one quarter of households being replaced each quarter. One can track unemployed who became unemployed in the same quarter when they were added to the survey. Although the overall sample size is large, the number of sampled individuals who can be tracked to compute hazards is small.
} 

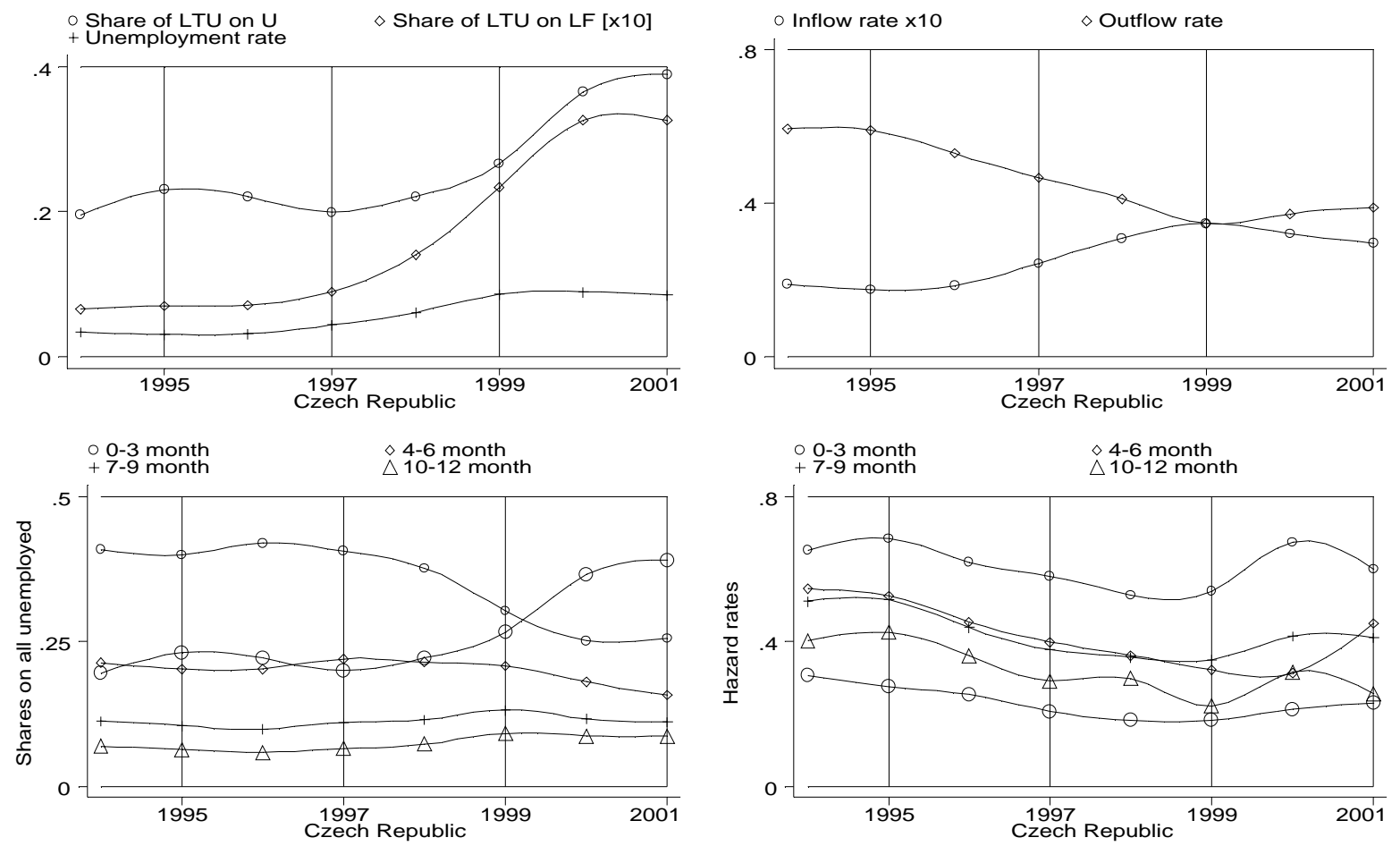

Figure 4.4: Duration Structure of Registered Unemployment

UR LTU incidence is 15 percentage points lower. ${ }^{15}$ Still, we see a rapid rise in UR LTU incidence from 20 to 40 percent between 1997 and 2001.

The upper right panel then shows the underlying annual unemployment inflow and outflow rates. ${ }^{16}$ We see a rapid decline in the outflow rate starting already in 1996, one year before the official start of the recession, while the inflow rate rose during the late 1990s. Fortunately, both trends were reversed starting in 1999. The drop in outflow was to a great extent due to a drop in aggregate demand represented by lower number of available vacancies. The post-recession outflow is also in

\footnotetext{
${ }^{15}$ Given that the overall unemployment rate is similar, the difference is likely due to different way of measuring unemploymetn length in the two data sets, for example due to delay in registering at the Labour Offices after losing employment.

${ }^{16}$ The inflow and outflow rates are defined, respectively, as the number of workers who enter the unemployment register in a given period divided by the total size of the labor force, and the number of workers leaving the register divided by the number of unemployed. We present annual averages of quarterly rates.
} 


\section{William Davidson Institute Working Paper 498}

part lower because more unemployed are now long-term unemployed and longer unemployment lowers job finding chances through genuine duration dependence.

We already know that UR LTU incidence doubled as a consequence of the recession. The bottom left graph of Figure 4.4 shows how the duration structure of the pool of registered unemployed has changed at durations shorter than one year. We see that at the start of the recession the increase in unemployment inflow balanced the drop in outflow and kept the duration structure fairly stable. However, starting 1998 there is a large drop in the share of very short-term unemployed (0-3 months) on all unemployed corresponding to the rapid rise in the share of LTU-those who entered unemployment in early recession in 1997 are not leaving the registers while the flow of new entrants is low. (The large-circle series replicates the share of LTU and is not to be confused with the small-circle series on short-term unemployment share.)

Finally, the bottom right graph of Figure 4.4 shows the outflow rates for different duration groups. We see that during the recession aggregate hazards were declining at a similar rate at all durations. This evidence is consistent with little change in duration dependence and implies that the rise in LTU is due to the drop in overall unemployment outflow and the rise in inflow. In other words, there are more long-term unemployed at the end of the recession only because the chances of all unemployed (long-term as well as short-term) have been equally reduced by the recession. Long-term unemployed are not worse off in 1999 compared to short-term unemployed than they were in 1995.

Moreover, in the last two years we see a mild, but sustained rise in the outflow rate of longterm unemployed. It appears that the economic recovery is not leaving the long-term unemployed behind. If this trend continues, both in terms of increasing overall outflow and in terms of similar patterns of outflow rates for short- and long-term unemployed, the share of LTU on all unemployed would gradually decrease. 

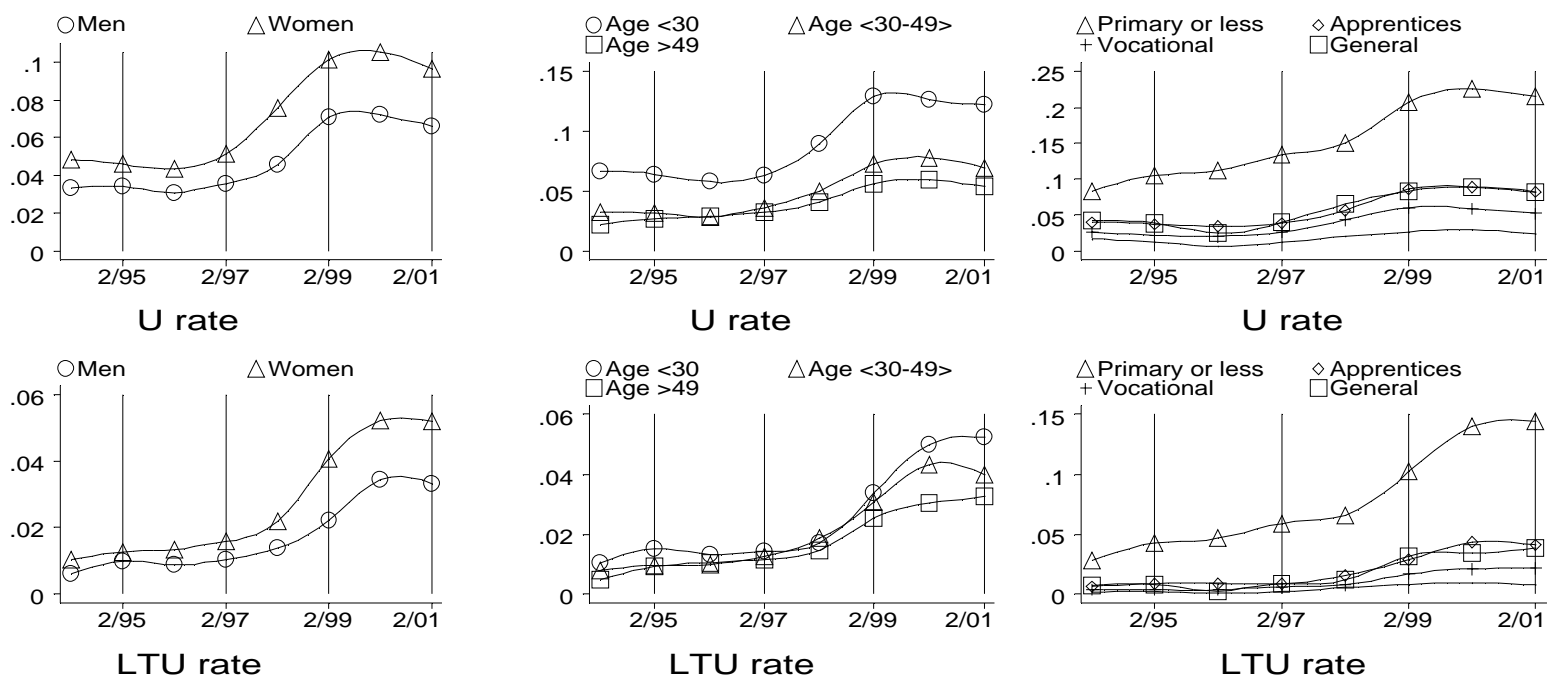

Figure 4.5: Demographic Structure of Unemployment and LTU

\subsection{Demographic, R egional and Industry Structure}

The aggregate outflow rates we analyzed above were declining with the duration of unemployment. A natural interpretation of this fact is that long-term unemployed have a lower chance of finding a job due to, e.g. loss of human capital, discouragement, stigma, etc. This is what is called true (genuine) duration dependence. But there is an alternative equally natural explanation which attributes the falling aggregate outflow rate to heterogeneity of the pool of unemployed (see, e.g., Machin and Manning, 1999). Moreover, the two hypotheses lead to different policy implications: In presence of significant heterogeneity one should favour retraining programs, while policies preventing the inflow into unemployment would be cost efficient if true duration dependence were quantitatively more important. To distinguish between the two forces behind the observed negative duration dependence, one must estimate micro-econometric models of unemployment duration allowing for unobserved heterogeneity (see, e.g., Jurajda, 2002). Estimation of such models is beyond the scope of the present paper. Instead, we provide a first descriptive look at the importance of observable worker characteristics in driving Czech LTU. 

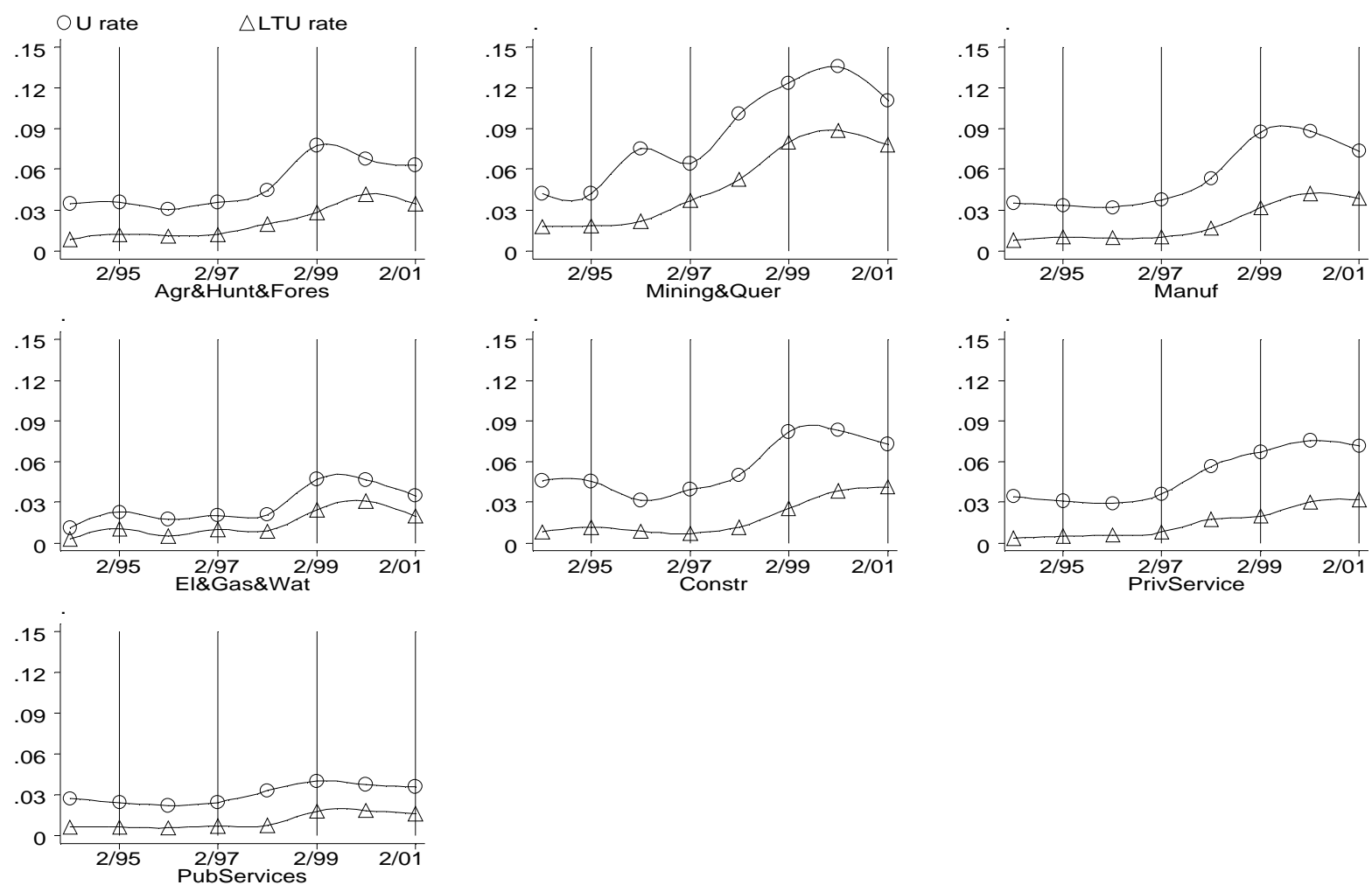

Figure 4.6: Industrial Structure of Unemployment and LTU

Figure 4.5 compares the unemployment and LTU rates for basic demographic groups. It is perhaps not surprising to see higher unemployment as well as LTU among women compared to men. Of course this comparison is affected by the higher probability of women to drop out of the labor force. The second pair of graphs compares the unemployment rates for different age groups. While the youngest workers (under 30) are more likely to be unemployed, their chances of being LTU are similar to those of the other groups until 1999. Finally, the third pair of graphs presents the comparison of unemployment by education level. There is a large difference of about 13 percentage points in both unemployment and LTU rates between the workers with only primary education and their more educated colleagues. Finally, the college-educated workers (represented by the line with 


\section{William Davidson Institute Working Paper 498}

no plotting symbols) enjoy almost zero chances of LTU. ${ }^{17}$

Next, Figure 4.6 asks about differences in LTU rates by the industry of workers' previous employment. The highest LTU rate is among workers formerly employed in mining, peaking at about 9 percent in 2000. The LTU rate is similar in all other industries, with the exception of public services, where both the unemployment and LTU rates are exceptionally low.

In Figure 4.7 we turn to the reason for termination of previous employment. Specifically, we compare the short-term and long-term shares on each group of unemployed based on the type of job loss. Consider the example of those who lost job because of firm closure. The upper left graph shows that their share on all on unemployment is similar to their share on LTU. The same holds for other groups, with the exception of workers leaving employment on health grounds, who are somewhat over-represented in the pool of LTU, suggesting higher chances of prolonged jobless spells. Overall, there are apparently no significant differences in the duration structure of unemployment based on the reason for termination of employment.

Figure 4.8 completes the search for worker characteristics related to LTU and explores the LTU differences by workers' previous occupation. As one would expect, given our findings of high LTU for low-educated workers, the LTU rates among machine operators and workers in elementary occupations are an order of magnitude larger compared to, e.g., professionals.

In sum, our exploration of demographic structure of LTU therefore points to low-educated and young workers together with workers separating from mining firms as the first potential target for retraining and other labor-market assistance programs.

Finally, we also ask about the district differences in the level of LTU and its persistence. Both are illustrated in Figure 4.9 which compares the district level of overall unemployment before and after

\footnotetext{
${ }^{17}$ Here, it is also relevant to note that the share of recent school graduates on all registered unemployed has oscillated around 10 percent until recently, when it grew to 14 percent. Recent school graduates form a similar fraction (12 percent) of all long-term unemployed. The position of school graduates calls for future research.
} 

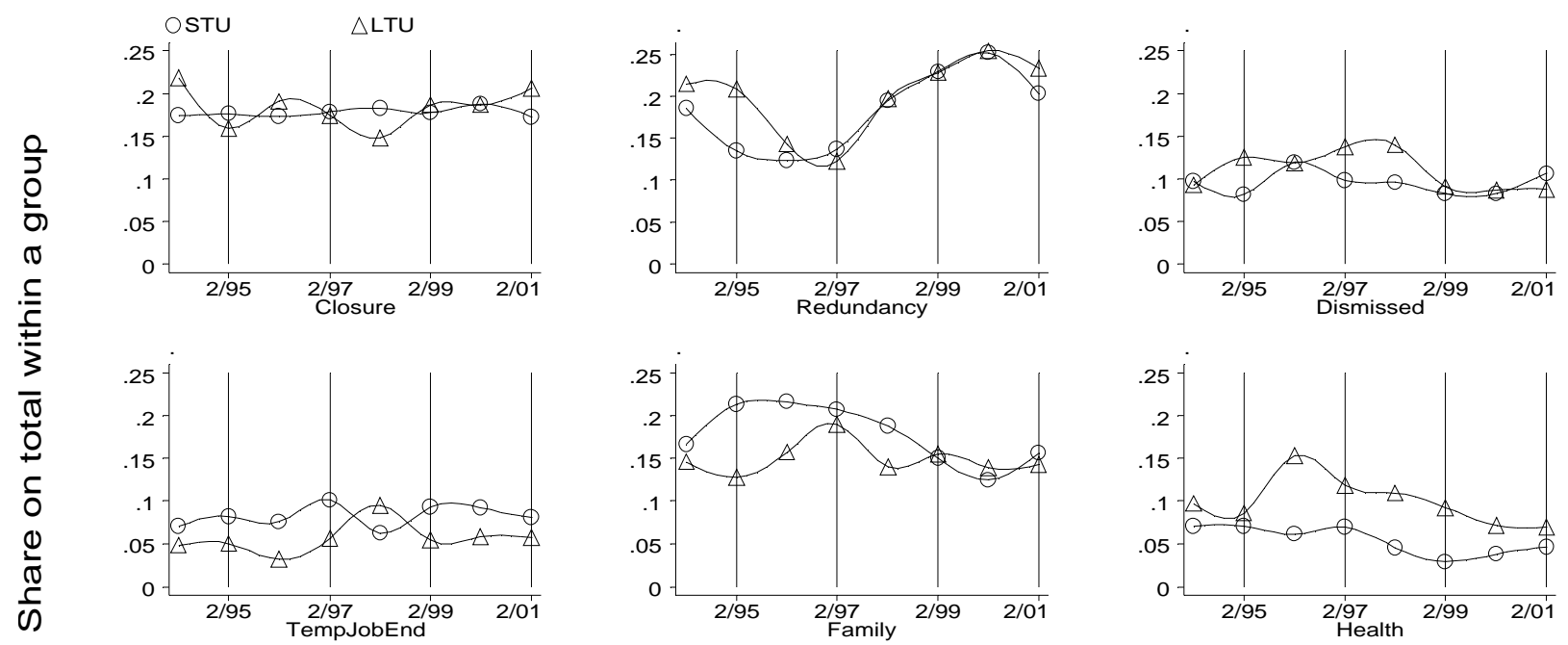

Figure 4.7: Unemployment by Reason for Job Termination

the recession. Each circle corresponds to one district pair of observations, with the size of the circle corresponding to the level of LTU incidence within the district in 2001. The overall unemployment rate ranges from around 3 percent to well over 15 percent for a significant number of districts. Comparing the position of the circles against the 45 degree line, we see that during the recession the number of unemployed has increased more in districts that were already facing relatively high unemployment. Furthermore, as one would expect, we see much higher LTU incidence in districts with higher level of unemployment and with higher increase in unemployment (larger distance from the 45 degree line). This feature of Czech LTU is particularly important given the low territorial mobility of the labor force (see, e.g., Fidrmuc and Huber, 2002).

\subsection{Links to Welfare}

A proper understanding of LTU can only be gained against the institutional background of a particular labor market. In this final section of the paper we focus on the role of the Czech welfare system. (The potential disincentive effects of welfare benefits were identified as one of the crucial features of the Czech labor market in our recent survey, see Jurajda et al., 1999.) To briefly highlight 


\section{William Davidson Institute Working Paper 498}
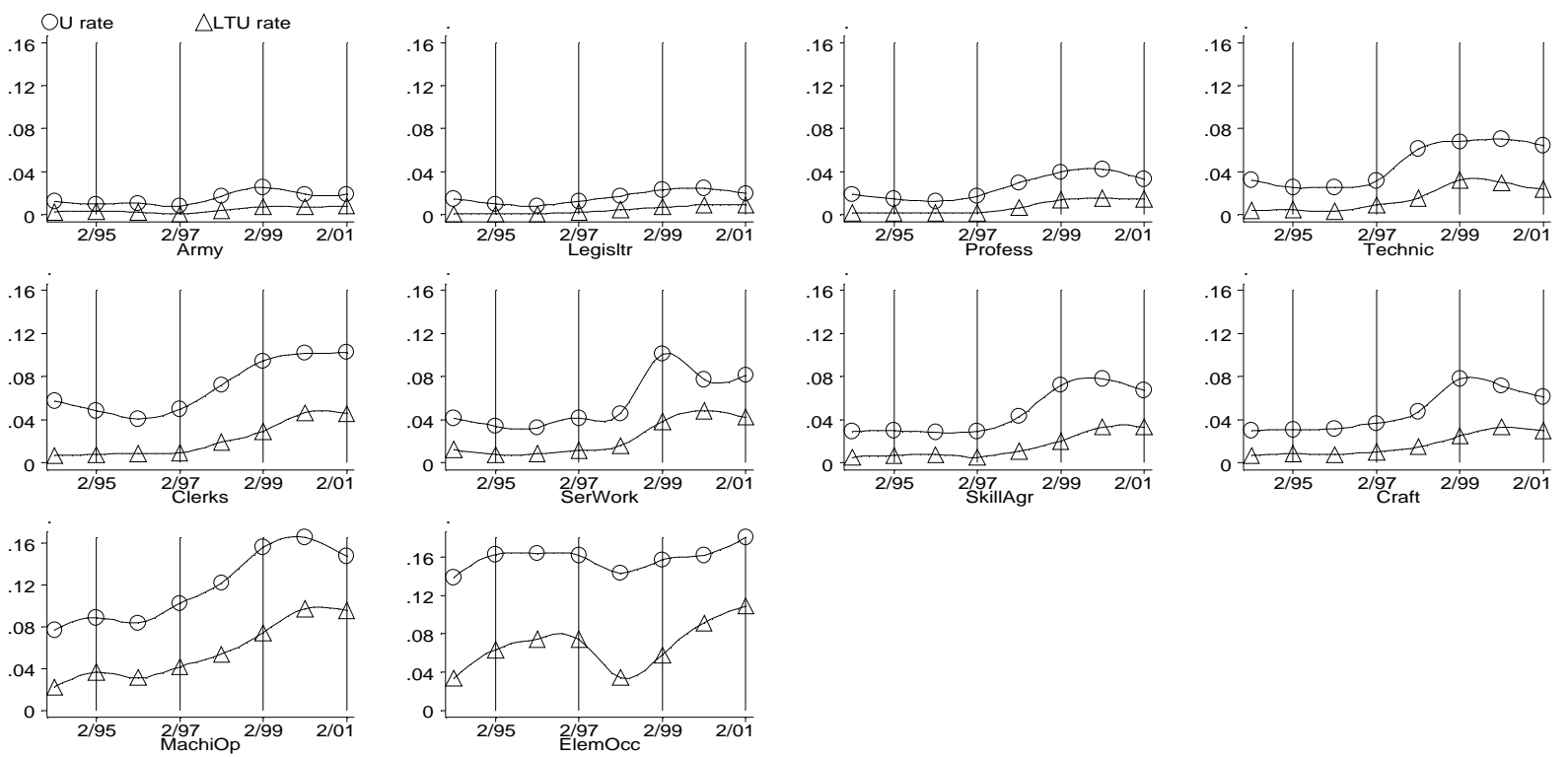

Figure 4.8: Unemployment and LTU by Previous Occupation

the main features of the Czech social assistance scheme we note that it is based on a two-income family model, and, as a consequence, the level of the legal minimum living standard for a family with two or more children is similar to the nation-wide average wage. Social benefits are subject to registration at the labour office, but do not expire.

Our goal is to suggest to what extent the generosity of the Czech welfare system can be linked to LTU. The answer would be ideally found using micro-econometric estimation of welfare participation of family members. Such exercises are very complex (see, e.g., Meyer and Rosenbaum, 2001, for references, or Card and Robins, 1998, for experimental evidence) and below we will perform only very simplified forms of analysis.

To analyze the impact of welfare generosity within any type of a model, one needs variation in the explanatory variable. There is little available time variation in the nationally-set level of social benefits, other than inflation adjustments. On the other hand, welfare benefits vary significantly (at the family level) depending mainly on the number of children, while wages do not; we therefore 


\section{William Davidson Institute Working Paper 498}

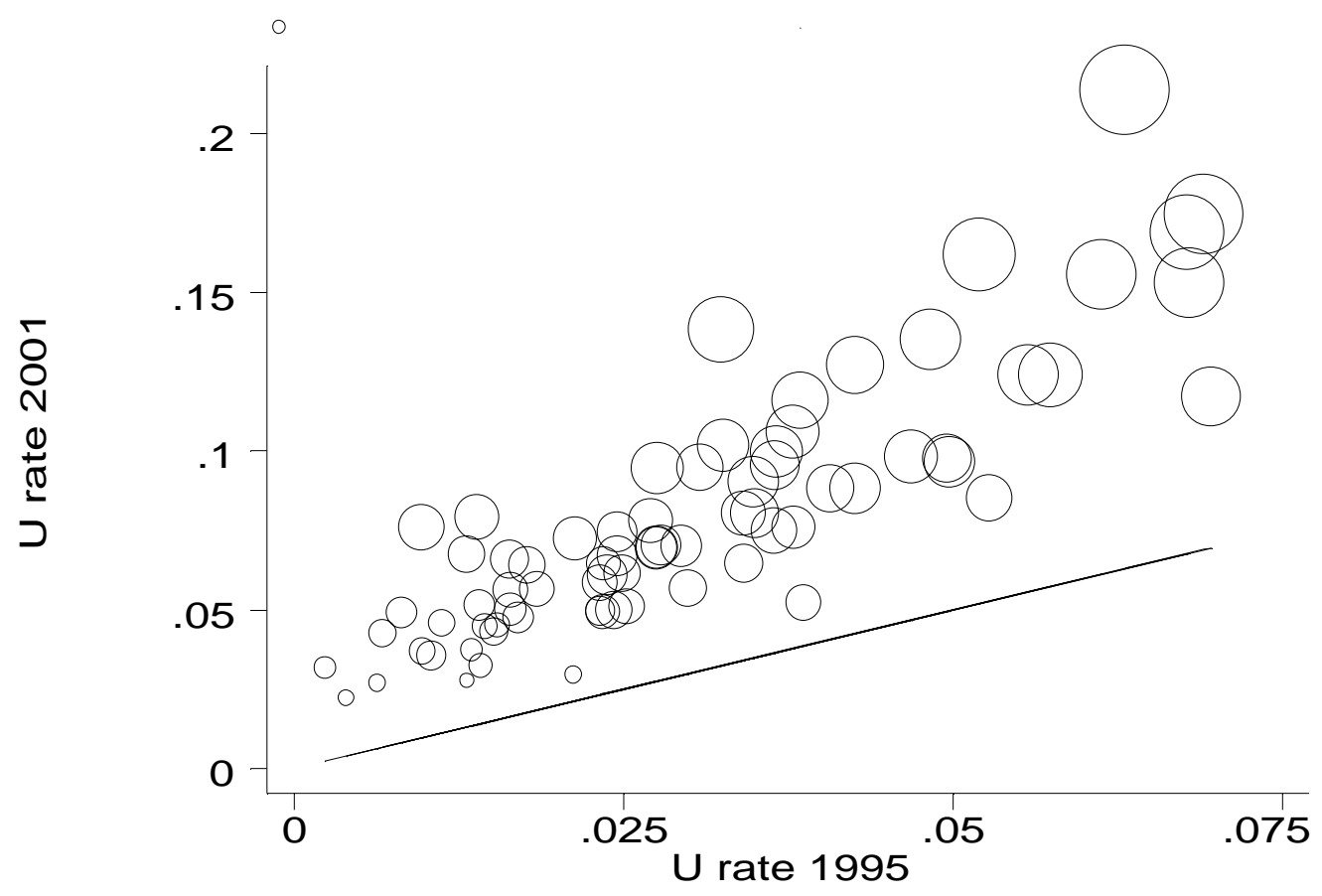

Figure 4.9: District Unemployment and LTU

use this variation to get at our question: We aim to explain welfare participation and LTU using the difference between potential labor-market earnings and potential welfare benefits at the family level.

We do not have available administrative micro data on collection of social benefits, but use the detailed information on family composition included in the LFS data to impute the available social benefits using the welfare formulas and assuming that families apply for and receive social benefits when eligible. Unfortunately, the LFS does not contain information on wages either. Therefore, to impute potential labor-market earnings, we estimate Mincerian wage regressions using the 1996 Microcensus individual-level data, use the estimated coefficients to predict wages of all individuals in the LFS sample, and adjust the predicted wages for inflation between 1996 and 2001. ${ }^{18}$ The

\footnotetext{
${ }^{18}$ Filer et al. (1999) suggest that the Czech wage structure has stabilized in the late 1990s. The wage regressions are estimated separately for men and women, control for education degree and a quadratic in age, and are not corrected
} 

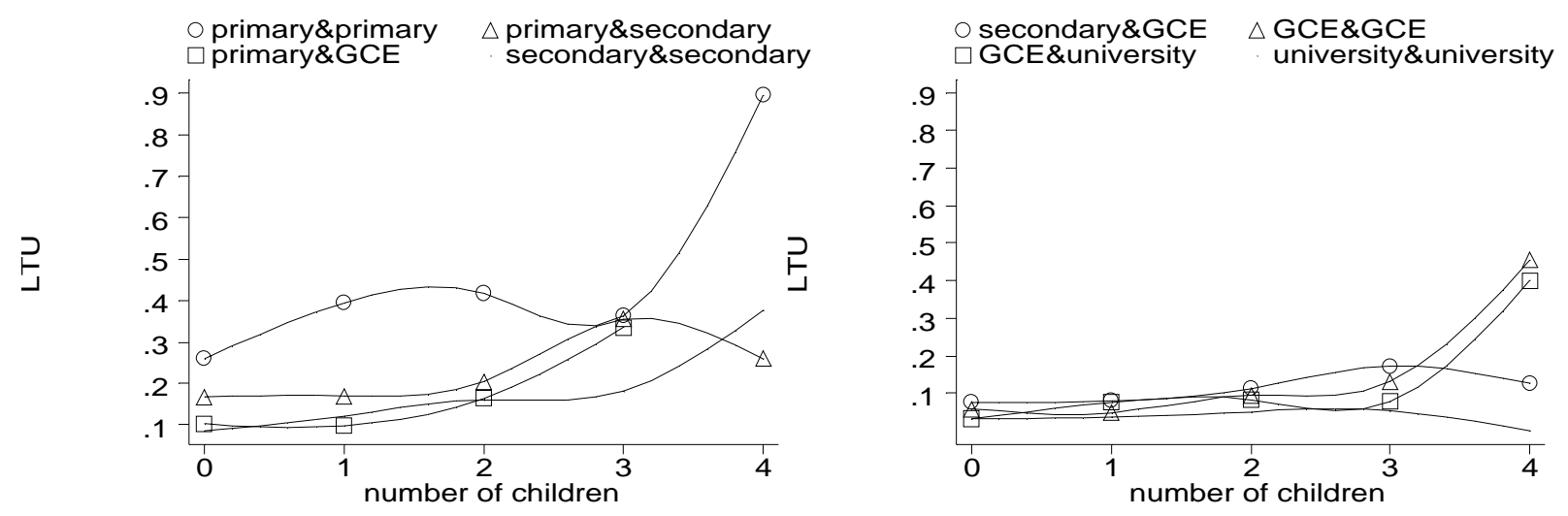

Figure 4.10: LTU and Family Composition

Microcensus data represent the most recent large household survey sample available; like the LFS, they are collected by the Czech Statistical Office. To simplify our analysis, we constrain the sample to two-adult families.

We start with a crude approximation based on the LFS data alone. The two graphs of Figure 4.10 plot the share of families with at least one long-term unemployed family member for each family type given by the highest education of parents and the number of children. There is a striking increase in LTU propensity in low-educated families when the number of children increases from three to four. While we learned of the high LTU propensity among workers with elementary (primary) education in Section 4.4, Figure 4.10 implies that 90 percent of families with four children where both parents have only primary education includes at least one long-term unemployed. The LTU propensity is also high, at about 40 percent, for 4-children families where parents have secondary education. ${ }^{19}$

Next, we use the imputed wage information to contrast the available welfare receipt at the family level with market earnings of individual family members. Table 4.2 presents the percentage share of four demographic groups in employment (E), long-term unemployment (LTU), and out-of-

for sample selection into employment.

${ }^{19}$ GCE refers to the Czech "maturita" exam, roughly corresponding to the General Certificate of Education. 
Table 4.2: Individual Employment Status and Potential Welfare-Wage Differences

\begin{tabular}{l|ccc|ccc|ccc}
\hline \hline & \multicolumn{3}{|c|}{ Welfare>Wage } & \multicolumn{2}{c|}{ Welfare<Wage } & \multicolumn{3}{c}{ Difference } \\
\multicolumn{1}{c}{ Percent of Group in } & E & LTU & OLF & E & LTU & OLF & E & LTU & OLF \\
\hline Men, spouse working & 96 & 2 & 2 & 97 & 1 & 2 & 1 & -1 & -1 \\
Men, spouse not working & 88 & 9 & 3 & 96 & 2 & 2 & 8 & -7 & -1 \\
\hline Women, spouse working & 75 & 10 & 15 & 86 & 4 & 10 & 10 & -6 & -5 \\
Women, spouse not working & 55 & 26 & 18 & 80 & 12 & 8 & 25 & -14 & -11 \\
\hline \hline
\end{tabular}

Source: Own computations based on 2001 LFS and 1996 Microcensus data adjusted for inflation.

labor-force (OLF), depending on whether the worker's predicted wage is above or below the welfare benefits level the family would be eligible for if none of its members were working. The Table suggests that the LTU probability of a man whose spouse is not working is 7 percentage points higher if his potential wage is above the available family welfare benefits. Similarly, the chance a woman whose spouse if jobless is long-term unemployed is 14 percentage points higher if her potential wages are below the available social benefits. ${ }^{20}$

The above comparisons are imprecise in that they contrast the individual-level wage with familylevel welfare benefits. Next, we therefore use as explanatory variable the ratio between the available family welfare and the sum of predicted wages for all adult family members. We regress this ratio on the family LTU status defined, for the sake of simplicity, as 1 if at least one of the adults is LTU and defined as 0 otherwise. The Probit probability derivatives calculated at the mean value of the explanatory variable are presented in the left panel of Table 4.3, together with observed and predicted LTU probabilities, for two alternative specifications. First, we use the ratio of welfare to wages as defined above in levels. Second, we use a log specification and allow the denominator to

\footnotetext{
${ }^{20}$ Considering only men who are long-term unemployed and whose spouse is not working, the available welfare is on average 2,225 Czech Crowns (CZK) higher than the predicted wage. For women, the corresponding gap is 4,799 CZK.
} 
Table 4.3: Probit Estimates of Welfare/Wage Effect on Family LTU

\begin{tabular}{l|cccc|cc}
\hline \hline & $\frac{\mathrm{dF}}{\mathrm{d} \overline{\mathrm{X}}}$ & Std. Err. & $\mathrm{P}$ & $\mathrm{\Phi}(\overline{\mathrm{X}})$ & $\frac{\mathrm{dF}}{\mathrm{dX}}$ & $\mathrm{\Phi}(\mathrm{X})$ \\
\hline Welfare/Wages & 0.30 & 0.015 & 0.111 & 0.104 & 0.371 & 0.136 \\
\hline $\ln$ (Welfare) & 0.110 & 0.015 & 0.110 & 0.102 & 0.146 & 0.152 \\
$\ln$ (Wages) & -0.249 & 0.019 & & & -0.330 & \\
\hline \hline
\end{tabular}

have a different coefficient from the numerator.

The estimates suggest a small effect of welfare benefits on LTU chances of an average family (with sufficiently high education and earnings). In the right panel of Table 4.3, we therefore evaluate the probability derivatives for low-education (low-income) families. Specifically, we calculate the effect for all families in which no one has attained more than an apprenticeship degree. The estimated coefficients imply that a $10 \%$ increase in minimum welfare standard does affect the LTU chances of such Czech two-adult families by increasing its chances of LTU by $1.4 \%$. The log specification suggests a similar overall impact.

\section{Conclusion}

We find a relatively large and growing incidence of LTU as over 50 percent of Czech unemployed in 2001 have been jobless for over a year (using the ILO definition). When placing this figure into international perspective, we point out comparability problems with using contemporaneous values of LTU across countries. To avoid some of these problems we use VAR-based simulations and find that the increase in Czech LTU during the recent recession appears small in comparison to a simulated response of the inflexible Spanish labor market. On the other hand, using a similar comparison, the Czech labor market seems somewhat inferior to that of the UK.

To understand the sources of LTU we consider its "accounting" inputs. We find that during the recent recession aggregate hazards were declining at all durations. Conditional on no change in the 


\section{William Davidson Institute Working Paper 498}

heterogeneity of the pool of unemployed during the recession, this evidence implies little change in the structure of duration dependence and allows us to attribute the rise in LTU solely to the lower overall outflow and higher inflow. Moreover, it appears that during 2000 and 2001 the economic upturn not only increased outflow rates at short durations, but also somewhat lifted the outflow rate for long-term unemployed, signalling a (mild) potential for decreasing LTU in near future.

Our descriptive analysis also searches for specific groups of workers who are most likely affected

by LTU. We find several factors increasing the incidence of long-term unemployment, most importantly low educational attainment. We also note that there are other factors, which do not seem to be strong determinants of LTU such as the reason for losing the previous employment. Finally, we suggest a significant effect of welfare generosity on families with more than 3 children and low-educated parents. 


\section{Bibliography}

Blanchard and Portugal (2001) "What Hides Behind an Unemployment Rate: Comparing Portugese and U.S. Labor Markets" A merican Economic Review, 91 (1): 187-207.

Blanchard and Diamond (1989) "The Beveridge Curve", B rookings Papers on E conomic Activity, 1.

Borjas, G.J. (1996) Labor E conomics. McGraw-Hill.

Calmfors (2001) "Unemployment, Labour-Market Reform and Monetary Union", J ournal of Labor Economics, vol. 19, No. 2.

Card, D., and P.K. Robins (1998) "Do Financial Incentives Encourage Welfare Recipients to Work?: Evidence from a Randomized Evaluation of the Self-Sufficiency Project," in Polachek, S.W., ed., Research in labor economics. Volume 17. Stamford, Conn. and London: JAI Press.

Castillo, S., Dolado, J.J., and J.F. Jimeno (1998) "A tale of two neighbor economies: Labour market dynamics in Spain and Portugal," CEPR Working Paper No.1954.

Fidrmuc, J., and P. Huber (2002) "The Puzzle of Rising Regional Disparities and Falling Migration Rates during Transition," ??

Filer, R.K., Jurajda, Š., and J. Plánovský (1999) "Education and Wages in the Czech and Slovak Republics During Transition," Labour E conomics, 6 (4), 581-593.

Gora, M., and C.M. Schmidt (1997) "Long-Term Unemployment, Unemployment Benefits and Social Assistance: The Polish Experience," WDI Working Paper No. 110.

Ham, J. C., Svejnar, J. and Terrell, K. (1998) "Unemployment and the Social Safety Net during Transitions to a Market Economy: Evidence from Czech and Slovak Republics," A merican Economic Review 88.

Jurajda, Š. (2002) "Estimating the Effect of Unemployment Insurance Compensation on the Labor Market Histories of Displaced Workers," J ournal of Econometrics, 108 (2), 227-252.

Jurajda, Š., Münich, D., and M. Čihák (1999) Background Study on Employment and Labour Market in the Czech Republic. European Training Fund.

Klugman, J., Micklewright, J. and G. Redmond (2002) "Poverty in the Transition: Social Expenditures and the Working-Age Poor," CEPR Discussion Paper No. 3389.

Layard N., Nickell, S., and Jackman, R. (1991). Unemployment. Macroeconomic Performance and the Labor M arket, Oxford University Press.

Machin, S. and A. Manning (1999): "The causes and consequences of long-term unemployment in Europe" in Ashenfelter and David (eds.), Handbook of Labor Economics, Volume 3. North-Holland. 


\section{William Davidson Institute Working Paper 498}

Meyer, B.D., and D.T. Rosenbaum (2001) "Welfare, the Earned Income Tax Credit, and the Labor Supply of Single Mothers," Quarterly J ournal of Economics, 116(3), 1063-1114.

Münich, D. (2002) "Job-seekers matching and Duration of Unemployment: The Case of the Czech and Slovak Republics," forthcoming as CERGE-EI Working Paper.

OECD (1999) Economic Surveys 1998: The Czech Republic, OECD, Paris.

Pissarides, C.A. (1990) Equilibrium Unemployment Theory. Oxford: Basic Blackwell.

Pissarides, C.A. (1992) "Loss of Skill during Unemployment and the Persistence of Employment Shocks," Quarterly J ournal of Economics. 107 (4): 1371-1391.

Svejnar, J. (1999) "Labor Markets in the Transitional Central and East European Economies," in Ashenfelter, O., and D. Card, eds. Handbook of Labor Economics, Elsevier Science B.V., pp. 2810-2857. 


\section{DAVIDSON INSTITUTE WORKING PAPER SERIES - Most Recent Papers}

The entire Working Paper Series may be downloaded free of charge at: www.wdi.bus.umich.edu

CURRENT AS OF 9/23/02

\begin{tabular}{|c|c|c|}
\hline Publication & Authors & Date \\
\hline No. 498: Understanding Czech Long-Term Unemployment & $\begin{array}{l}\text { Štěpán Jurajda and Daniel } \\
\text { Münich }\end{array}$ & Aug. 2002 \\
\hline $\begin{array}{l}\text { No. 497: Rent Seeking and Government Ownership of Firms: An } \\
\text { Application to China's Township-Village Enterprises }\end{array}$ & Jiahua Che & Sep. 2002 \\
\hline No. 496: Labor Market Flexibility in Central and East Europe & Jan Svejnar & Aug. 2002 \\
\hline $\begin{array}{l}\text { No. 495: When Information Dominates Comparison: A Panel Data } \\
\text { Analysis Using Russian Subjective Data }\end{array}$ & Claudia Senik & May 2002 \\
\hline No. 494: Corruption and Cross-Border Investment: Firm Level Evidence & $\begin{array}{l}\text { Beata K. Smarzynska and Shang- } \\
\text { Jin Wei }\end{array}$ & Aug. 2002 \\
\hline $\begin{array}{l}\text { No. 493: Modeling Sequences of Long Memory Positive Weakly } \\
\text { Stationary Random Variables }\end{array}$ & Dmitri Koulikov & Aug. 2002 \\
\hline $\begin{array}{l}\text { No. 492: Effects of Ownership and Financial Status on Corporate } \\
\text { Environmental Performance }\end{array}$ & $\begin{array}{l}\text { Dietrich Earnhart and Lubomír } \\
\text { Lízal }\end{array}$ & Aug. 2002 \\
\hline $\begin{array}{l}\text { No. 491: Does Economic Uncertainty Have an Impact on Decisions to } \\
\text { Bear Children? Evidence from Eastern Germany }\end{array}$ & $\begin{array}{l}\text { Sumon Kumar Bhaumik and } \\
\text { Jeffrey B. Nugent }\end{array}$ & July 2002 \\
\hline $\begin{array}{l}\text { No. 490: The Reallocation of Workers and Jobs in Russian Industry: } \\
\text { New Evidence on Measures and Determinants }\end{array}$ & J. David Brown and John S. Earle & Aug. 2002 \\
\hline $\begin{array}{l}\text { No. 489: The Incidence and Cost of Job Loss in a Transition Economy: } \\
\text { Displaced Workers in Estonia, 1989-1999 }\end{array}$ & $\begin{array}{l}\text { Hartmut Lehmann, Kaia Phillips } \\
\text { and Jonathan Wadsworth }\end{array}$ & Aug. 2002 \\
\hline No. 488: Integration: An Empirical Assessment of Russia & $\begin{array}{l}\text { Daniel Berkowitz and David N. } \\
\text { DeJong }\end{array}$ & Feb. 2002 \\
\hline $\begin{array}{l}\text { No. 487: Dual Inflation under the Currency Board: The challenges of } \\
\text { Bulgarian EU accession }\end{array}$ & $\begin{array}{l}\text { Nikolay Nenovsky and Kalina } \\
\text { Dimitrova }\end{array}$ & July 2002 \\
\hline $\begin{array}{l}\text { No. 486: Worker Flows, Job Flows and Firm Wage Policies: } \\
\text { An Analysis of Slovenia }\end{array}$ & $\begin{array}{l}\text { John Haltiwanger and Milan } \\
\text { Vodopivec }\end{array}$ & July 2002 \\
\hline $\begin{array}{l}\text { No. 485: Do Schumpeterian Waves of Creative Destruction Lead to } \\
\text { Higher Productivity? Panel Data Evidence from Poland }\end{array}$ & Frederic Warzynski & July 2002 \\
\hline $\begin{array}{l}\text { No. 484: Labor Market Institutions and Restructuring: Evidence from } \\
\text { Regulated and Unregulated Labor Markets in Brazil }\end{array}$ & Jasper Hoek & July 2002 \\
\hline $\begin{array}{l}\text { No. 483: The Balassa-Samuelson effect in Central and Eastern Europe: } \\
\text { Myth or reality? }\end{array}$ & $\begin{array}{l}\text { Balázs Égert, Imed Drine, Kirsten } \\
\text { Lommatzsch and Christophe } \\
\text { Rault }\end{array}$ & July 2002 \\
\hline No. 482: Real Exc & Boštjan Jazbec & July 2002 \\
\hline $\begin{array}{l}\text { No. 481: Labor Force Participation Dynamics in the Romanian Labor } \\
\text { Market }\end{array}$ & Alexandru Voicu & July 2002 \\
\hline $\begin{array}{l}\text { No. 480: Equilibrium Real Exchange Rates in Central Europe's } \\
\text { Transition Economies: Knocking on Heaven's Door }\end{array}$ & Balázs Égert & July 2002 \\
\hline $\begin{array}{l}\text { No. 479: The Impact of Minimum Wages on Wage Inequality and } \\
\text { Employment in the Formal and Informal Sector in Costa Rica }\end{array}$ & $\begin{array}{l}\text { Fatma El-Hamidi and Katherine } \\
\text { Terrell }\end{array}$ & Apr. 2001 \\
\hline $\begin{array}{l}\text { No. 478: Beyond Oaxaca -Blinder: Accounting for Differences in } \\
\text { Household Income Distributions }\end{array}$ & $\begin{array}{l}\text { François Bourguignon, Francisco } \\
\text { H. G. Ferreira and Phillippe G. } \\
\text { Leite }\end{array}$ & Feb. 2002 \\
\hline $\begin{array}{l}\text { No. 477: Participation Behavior of East German Women after German } \\
\text { Unification }\end{array}$ & Holger Bonin and Rob Euwals & July 2002 \\
\hline No. 476: Duration and Risk of Unemployment in Argentina & $\begin{array}{l}\text { Sebastian Galiani and Hugo A. } \\
\text { Hopenhayn }\end{array}$ & Oct. 2001 \\
\hline $\begin{array}{l}\text { No. 475: After, Before and During: Returns to Education in the } \\
\text { Hungarian Transition }\end{array}$ & $\begin{array}{l}\text { Nauro F. Campos and Dean } \\
\text { Jolliffe }\end{array}$ & Apr. 2002 \\
\hline No. 474: The Locking-in Effect of Subsidized Jobs & Jan C. van Ours & June 2002 \\
\hline No. 473: How Reform Worked in China & Yingyi Qian & June 2002 \\
\hline No. 472: An Economic Perspective on Russia's Accession to the WTO & Robert M. Stern & June 2002 \\
\hline
\end{tabular}

